\title{
HARMONISASI HUKUM \\ NEGARA-NEGARA ASEAN DALAM \\ RANGKA AFTA DAN HARMONISASI \\ HUKUM PERDAGANGAN \\ INTERNASIONAL PADA UMUMNYA.
}

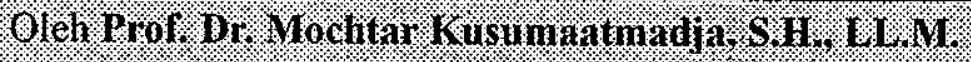

AFTA muncul sebagai suatu upaya merespon perkembangan dari pasar global yang makin terasa. Karena AFTA melibatkan banyak negara maka kehadirannya membutuhkan komitmen dan kesiapan bersama. Dan Mochtar yang mantan Menlu RI itu melihat perlunya harmonisasi hukum diantara negara-negara ASEAN dalam rangka AFTA tersebut.

\section{Pendahuluan}

Berbicara tentang topik "Perkembangan Kerjasama dan Harmonisasi Hukum Negara-Negara ASEAN dalam rangka ASEAN Fre Trade Area (AFTA)", saya akan membagi pembicaraan dalam dua bagian : (1) Harmonisasi yang perlu dilakukan bertalian dengan AFTA ; (2) Harmonisasi dalam Hukum Perdagangan International pada umumnya.

Hal ini saya lakukan karena AFTA mau tidak mau merupakan bagian dari dunia perdagangan yang lebih besar yang meliputi seluruh dunia, sehingga kita tidak bisa menghindarkan diri untuk t tidak membicarakan Hukum Perdagangan International secara umum. Hal ini akan menyangkut perananan United Nations Commission on International Trade Law.
(UNCITRAL) yang merupakan badan Perserikatan Bangsa-Bangsa (PBB) yang kompeten yang diserahi tugas melakukan unifikasi dan harmonisasi Hukum Perdagangan International.

\section{Masalah Dasar di bidang Hukum} antar Negara ASEAN

Dalam masalah dasar saya maksudkan adalah tidak semua anggota ASEAN mempunyai sistem hukum yang sama, terutama hukum perdata dan dagang. Sebagai bekas jajahan Inggris, Malaysia dan Singapura sistemnya didasarkan atas sistem common law, sedangkan Filipina didasarkan atas sistem hukum Amerika. Indonesia dan Thailand didasarkan atas sistem Hukum Sipil (eropa) dengan perbedaan, Thailand mempunyai Kitab. Undang-Undang Perdata 
yang mencontoh pada Civil Gazete-Buch Swiss, sedangkan Indonesia Masih menggunakan sebagai pegangan Kitab Undang-Undang Hukum Perdata dan Kitab Undang-Undang Hukum Dagang Belanda dari tahun 20-an dan 30-an.

Paling tidak Hukum Perikatan dan Hukum Perseroan yang merupakan dasar minimal bagi Hukum Sipil hendaknya dan sebaiknya ada persamaan atau harmonisasi. Hal ini sudah saya anjurkan pada pidato pembukaan Asian Law Association sewaktu badan ini didirikan di Manila tahun 1976 dengan maksud supaya paling tidak dalam Hukum Perdata dan Hukum Perseroan ada persamaan-persamaan mendasar yang memudahkan pengaturan kemudian segala sesuatu yang menyangkut hal ikhwal hubungan perdata dan perdagangan.

Ditarạ nasional usaha memodernisasikan kedua bidang hukum ini melalui pengajuan rancangan undang-undang, masing-masing RUU Perikatan (atau Perjanjian) dan RUU Perseroan Terbatas belum terealisasikan hingga kini walaupun RUU-nya sudah diajukan sejak tahun 1976/1977. Ini suatu contoh rendahnya prioritas soal-soal hukum di negeri kita. Memang mengenai hubungan dan perdagangan internasional sekarang sudah banyak kontrak-kontrak standar dan kita tahu juga, bahwa sedang berkembang international business transaction. Akan tetapi, alangkah baiknya kalau sebagai dasar atau jangkar posisi hukum nasional kita, kita mempunyai undang-undang nasional yang didasarkan pada asas-asas yang ada keserasian mendasar dengan sistem-sistem hukum lain. Demi kepentingan ekonomi dan pembangunan nasional kita sebagai bangsa harus mempunyai hukum nasional yang dapat dimengerti dan ada dasar-dasar persamaannya dengan hukum asing atau hukum intemasional. Tanpa itu dalam soal domisili hukum yuridiksi pengadilan kedudukan kita akan sangat lemah, karena kita tidak mempunyai dasar untuk menuntut suatu perkara diadili menurut hukum Indonesia.

Dalam banyak hal undang-undang yang mendasar semacam ini di bidang perdata dan dagang termasuk penyelesaian sengketa atau peradilan masih sangat kurang berkembang (undeveloped). Sebenarnya perangkat hukumnya sudah ada baik di bidang arbitrase, baik dagang (ICC dan UNCITRAL) maupun penanaman modal (ICSID), namun sarana untuk menyelesaikan sengketa itu disini atau melaksanakan putusannya agak kurang mantap. ${ }^{1)}$

Dibandingkan dengan negara ASEAN lain, hal ini jelas merupakan kendala bagi investor-investor asing yang berasal dari negara-negara yang menganggap peranan hukum dalam perdagangan itu penting, kebanyakan negara-negara Eropa, Amerika Serikat dan Canada. Itu sebabnya perusahaan Amerika Serikat Kebanyakan baru bergerak di bidang pertambangan dan enerji yang memang mempunyai dasar hukum tersendiri yang sudah jauh berkembang didasarkan pada undang-undang Pertambangan, dan undang-undang Minyak dan Gas Bumi tahun 1960 dan 1967, dengan bentuk hukum yang digunakan adalah Kontrak Karya dan Production Sharing Contract. Di luar itu, perusahaan besar dari Amerika dan Eropa kebanyakan merupakan kelanjutan dari perusahaan-perusahaan yangada di Indonesia sejak lama. Yang lainnya agak segan karena tidak ada jaminan tentang hal-hal mendasar serta tidak adanya sarana hukum dan peradilan yang menurut mereka dapat menjamin kelancaran kemudahan dan penyelesaian perkara dengan cepat. Dalam hal cauntry risk asessment ini merupakan hal

1) Dengan Peraturan Mahkamah Agung Nomor 1 Tahun 1990 soal tersebut sudah dapat diselesaikan. 
yang penting, bagi negara tertentu faktor yang menentukan.

ASEAN Law Association sudah banyak melakukan kegiatan kearah harmonisasi hukum antar negara ASEAN walaupun kegiatan' itu masih bersifat perbandingan. Tetapi inipun sudah sangat bermanfaat karena memudahkan langkah berikut dalam harmoninsasi, yang berikut adalah penyesuaian atau penserasian. Langkah berikutnya lagi adalah penyamaan, kemudian penyatuan, tetapi hal itu agaknya merupakan sasaran yang masih jauh.

Mengenai aspek-aspek hukum yang menyangkut AFTA itu sendiri perlu kita katakan secara garis besar yang terkait dengan pelaksanaan AFTA adalah: (1) ketentuan-ketentuan ekspor dan impor masing-masing negara ASEAN yang perlu diselaraskan dengan pelaksanaan AFTA; (2) ketentuan-ketentuan bea-cukai atas impor dan ekspor atau Ialu lintas barang dalam AFTA; (3) kategorisasi adan penyebutan barang-barang dan satuan-satuan barang sesuai dengan penamaan atau nomen-klatur bea cukai yang diterima umum oleh semua negara peserta yang sudah menandatangani perjanjian-perjanjian bea-cukai dan meratifikasinya; (4) prosedur kemudahan pemasukan barang yang diatur dalam Tokyo Convention on Simplication of Custom Procedur Tahun 1956; (5) lain-lain ketentuan yang menyangkut kelancaran lalu lintas barang. antar negara ASEAN termasuk pengangkutan dan kepelabuhanan.

Nampaknya memang AFTA hanya menyangkut lalu lintas perdagangan antar negara ASEAN, sehingga ruang lingkup pengaturan kerjasama ekonomi hanya terbatas pada perdagangan antar negara ASEAN.

Itupun mungkin hanya terbatas (bea-cukai) dan satu dua non-tarif barrier saja. AFTA bukan bentuk kerjasama ekonomi seperti Masyarakat Eropa yang meliputi lain-lain bidang ekonomi selain perdagangan, termasuk lalu lintas pekerja dan orang, dan segala kegiatan lainnya yang menyangkut kegiatan ekonomi antar negara. Dengan kata lain AFTA ini merupakan langkah awal dalam kerja sama ekonomi antar ASEAN yang masih terbatas pada perdagangan.

Dibandingkan dengan persetujuan peningkatan perdagangan sebelumnya antar ASEAN yang dinamakan ASEAN Preferential Trading Arrangement (PTA), diharapkan dengan AFTA ini lebih efektif. PTA yang telah berlangsung beberapa tahun merupakan usaha untuk meningkatkan perdagangan antara negara-negara ASEAN. Walaupun sudah berlangsung cukup lama, hasilnya sangat minim karena cara yang ditempuh berupa pengurangan tarif menurut jenis atau kelompok barang per kelompok dan jenis. Ada kecenderungan dalam pelaksanaan sistem ini, negara-negara ASEAN memilih kelompok, jenis atau satuan barang yang tidak begitu menimbulkan dampak negatif bagi kepentingan ekonomi negaranya. Akibatnya adalah setiap penambahan satuan barang (item) menghasilkan bertambahnya mata satuan atau yang diatur oleh PTA nampak besar, namun dampak keseluruhannya pada peningkatan perdagangan antara negara-negara ASEAN sangat kecil.

Walaupun AFTA merupakan kelanjutan dari usaha peningkatan perdagangan antara ASEAN bisa dianggap sebagai kelanjutan dari PTA, namun sebagai sistem, sebenamya berbeda secara drastik karena cara yang digunakan dalam AFTA adalah pengurangan bea masuk/ke luar yang menyeluruh (across the brand reduction) secara bertahap. Karena permintaari Indonesia dan Filipina, pelaksanaan AFTA dikaitkan dengan Common Effective Preferential Tariff (CEPT) yang merupakan suatu mekanisme untuk menselaraskan turut sertanya Indonesia dan Filipina secara bertahap dalam AFTA dalam jangka waktu lima belas tahun. 
Mengenai pertanyaan apakah perdagangan antara negara ASEAN bisa ditingkatkan dengan AFTA saja tidak bisa dijawab begitu saja, karena peningkatan perdagangan antara ASEAN juga ditentukan oleh hambatan-hambatan non tarif (non-tariff barrier). Yang paling dikenal dalam hambatan non-tarif ini diantaranya adalah kuota. Selain paling dikenal mudah diadministrasikan, sistem kuota sebagai hambatan non-tarif juga paling mudah terlihat.

Selain kuota masih ada hambatan non-tarif yang lain yang sebenarnyakurang terlihat sebagai hambatan non-tarif, tetapi sebenamya sangat menentukan untuk menjawab pertanyaan apakah suatu kerjasama perdagangan antara negara merupakan satu blok ekonomi atau bukan. Dengan kata lain apakah disamping diturunkannya tarif sebagai pagar antara perdagangan ASEAN (pagar dalam), tidak didirikan pagar lain yang merupakan penghalang perdagangan antara negara ASEAN dengan negara di Iuar ASEAN (pagar luar atau outer wall). Sebenarnya hal ini bisa dilakukan secara tidak kelihatan dengan berbagai cara. Yang paling sering digunakan adalah syarat muatan atau komponen lokal (local content requirement). Tinggi rendahnya komponen lokal sebenamya menentukan kulifikasi atau sifat apakah suatu persatuan perdagangan negara merupakan suatu free trade area yang mengurangi perdagangan dengan pihak luar atau tidak.

Dengan kata lain persyaratan komponen lokal tersebut merupakan suatu hambatan yang tidak mudah dilihat. Secara mudah dapat dikatakan, bahwa makin tinggi persyaratan komponen lokal, makin persatuan kerjasama perdagangan antara negara itu merupakan suatu blok dengan mendirikan outer wall walaupun tetap dinamakan free trade area. Suatu free trade area yang menambahkan persyaratan kompo- nen lokal $80 \%$ misalnya, jelas merupakan trading block apapun namanya, dengan argumen apapun diajukan kepada pihak luar. Dalam kenyataannya, suatu sistem demikian merupakan suatu blok perdagangan.

Cara-cara Iain yang lebih canggih adalah syarat-syarat kesehatan, karantina, dan prosedur administrasi yang rumit, komplek atau berbelit-belit. Secara resmi syarat-syarat ini bukan merupakan tarif dan tidak mendirikan tembok penghalang, tetapi secara efektif mereka mempersulit ekspor ke negara yang mengadakan syarat-syarat itu.

\section{Harmonisasi Perdagangan \\ Internasional Secara Umum}

Setelah Perang Dunia I telah ada usaha-usaha untuk menyatukan atau paling tidak menyerasikan hukum yang bersangkutan dengan perdagangan internasional termasuk penyelesaian perselisihannya. Usaha ini dilakukan baik oleh pemerintah maupun badan-badan swasta non-pemerintah.

Konferensi De Haag pada tahun 1920-an misalnya menghasilkan beberap konvensi yang mengatur perdagangan internasional, antara lain di bidang pengangkutan laut: convention on carriage of goods by yang kemudian dikenal sebagai The Hague Rules. ${ }^{2}$ ) Di bidang penyelesaian sengketa perdagangan yang sangat aktif adalah International Chamber of Commerce yang berkedudukan di Paris yang menyusun ketentuan-ketentuan mengenai arbitrase intemasional di bidang perdagangan. Ada juga lembaga swasta di Roma yang dinamakan Rome Instutute yang melahirkan ketentuan-ketentuan mengenai arbitrase perdagangan yang disebut International Convention on Arbitration.

2) Ditandatangani di Brussel tahun 1924. 
Setelah Perang Dunia II banyak timbul negara-negara baru yang tadinya merupakan jajahan. Negara-negara baru ini ingin memegang peranan dalam membentuk hukum yang akan mengatur hubungan internasional baik dibidang perdagangan maupun hukum internasional publik. Di dalam hukum intemasional publik kita kenal usaha-usaha mereka lakukan dalam bidang Hukum Laut misalnya.

Ternyata tidak mudah untuk negara-negara yang baru dan sedang berkembang untuk memainkan peran secara efektif dalam usaha merubah ketentuanketentuan hukum internasional di bidang perdagangan yang selain menyangkut penyelesaian perselisihan, juga menyangkut hukum pengangkutan laut, hukum yang mengatur jual beli barang (sale of goods), dan lain-lain masalah yang menyangkut perdagangan serta hal-hal yang bersangkutan dengan itu. Usaha untuk merubah The Hague Rules yang mengatur pengangkutan laut misalnya jauh dari mudah dan dengan susah payah melalui forum PBB kemudian bisa disusun konvensi baru yang mengatur pengangkutan barang melalui laut (carriage of goods by sea) yang menggantikan The Hague Rules. Naskah konvensi baru yang disusun untuk menggantikan The Hague Rules ini kini secara populer disebut hamburg Rules. Dibandingkan dengan The Hague Rules yang ditentukan negara-negara maju karena pada waktu itu belum ada negara berkembang, Hamburg Rules merupakan kemajuan karena ia merupakan hasil bersama negara maju dan negara berkembang, dan yang lebih penting lagi ia merupakan perpaduan antara sistem hukum yang berlainan, yaitu hukum pengangkutan laut yang secara tradisonal sebagian besar didasarkan pada hukum pengangkutan laut Inggris dan hukum negara-negara eropa kontinental ditambah lagi dengan sumbangan pikiran dari negara- negara merdeka yang baru berkembang.
Berdasarkan pengalaman yang diperoleh dalam menyusun konvensi-konvensi baru dalam bidang perdagangan intemasional melalui prosedur. PBB yang konvensional diatas, kemudian timbul pikiran untuk membentuk badan khusus PBB yang berkewajiban menyusun dan mengembangkan hukum internasional baru di bidang perdagangan internasional.

Pertimbangan yang mendorong dibentuknya badan khusus ini yaitu United Nations Commission on International Trade Law (UNCITRAL) adalah pandangan, bahwa hukum perdagangan internasional itu merupakan hukum yang disusun negara kapitalis. Pandangan ini umumnya dianut negara-negara eropa timur yang dulu dinamakan negara komunis. Baru kemudian mereka menyadari, bahwa walaupun disusun negara kapitalis, hukum perdagangan internasional itu pada hakekatnya netral dalam arti politik dan bersifat universal. Pertimbangan lain bagi PBB membentuk UNCITRAL adalah karena bagian-bagian penting hukum yang menyangkut hukum perdagangan internasional atau hubungan ekonomi banyak yang disusun badan-badan khusus yang mempunyai kompetensi atau wewenang di bidang khusus masing-masing seperti International Telecomunication Union (ITU), yang selain mengatur hal ikhwal telekomukasi juga menyusun konvensikonvensi di bidang telekomunikasi. International Maritime Organization (IMO) menyusun hukum intemasional di bidang perhubungan laut dan maritim pada umumnya. Sama halnya dengan WHO, ILO, dan badan- badan khusus PBB lainnya.

Sejak didirikannya pada tahun 1966 dengan Resolusi Sidang Umum PBB, UNCITRAL telah banyak melakukan kegiatannya, antara lain :

1.Mengkoordinasi pekerjaan badan-badan khusus PBB yang bertalian dengan hukum perdagangan intemasional. 
2. Mengadakan penelaahan dan pengkajian hasil kerja lain-lain organisasi baik regional maupun internasional untuk melihat apakah pekerjaan mereka itu tepat (appropriate);

3. Sebagianbesar waktu UNCITRAL (kurang lebih $80 \%$ dipakai untuk menyusun naskah-naskah UNCITRAL sendiri tentang contoh-contoh konvensi (drafi convention), hukum (model laws), dan contoh-contoh kontrak (contract) serta beberapa pedoman (guide dan guide-lines);

4. Tugas interpretasi dari ketentuanketentuan yang diambil pemerintah, pengadilan, dan badan-badan internasional yang menyangkut hukum perdagangan internasional.

Tugas yang keempat ini bukan tugas yang mudah, karena negara-negara berbeda menerapkan atau mengimplementasikan teks yang universal berlaku. Hal ini disebabkan karna badan-badan legislatif nasional dalam mengimplementasikan perjanjian- perjanjian yang universal melakukannya dengan pelbagai cara. Misalnya hanya mempublikasikan naskah asli konvensi atau perjanjian universal, mempublikasikan terjemahan perjanjian internasional itu dalam bahasa nasional atau kadang mempublikasikan naskah yang sudah dirubah (mofied text).

Dalam melaksanakan tugas interpretasi ini UNCITRAL belum banyak keseragaman interpretasi (uniform interpretation). Akan tetapi, UNCITRAL setidak-tidaknya telah mulai mengadakan kumpulan-kumpulan keputusan administrasi pengadilan dan interpretasi nasional naskah-naskah UNCITRAL dan konvensi-konvensi yang disusun UNCITRAL.

UNCITRAL bermaksud membuat abstrak atau summary keputusan-keputusan di atas dalam semua bahasa resmi PBB untuk dibagikan kepada pemrintah anggota $\mathrm{PBB}$ dan semua pihak yang menaruh minat. Segala pekerjaan yang menyangkut interpretasi ini terutama yang dilakukan dengan bantuan koresponden-korespondenyang dipelbagai negara (national correspondent). Peranan national correspondent ini ternyata sangat bermanfaat misalnya dalam hal Konvensi tentang Jual Beli Barang (UNCITRAL Sale of Goods Convention).

Tugas harmonisasi hukum oleh UNCITRAL dilakukan dengan cara berikut : (1) ditingkat perundang-undangan, dengan teknik konperensi kodifikasi; (2) dengan menggunakan naskah contoh (model convention atau model contracts).

Cara yang pertama atau condification conference mempunyai keuntungan, bahwa dengan teknik ini dicapai keseragaman bentuk (uniformity) kecuali apabila peserta membuat resevasi (reservation). Kadangkadang untuk mencegah diadakannya reservasi demikian, reservasi dilarang di dalam konvensi yang bersangkutan.

Teknik model laws atau model contracts lebih luwes. Untuk menjamin suatu tingkat keserasian atau kesamaan (harmony atau uniformity) yang lebih besar, seringkali teknik model law atau model contract disertai rekomendasi untuk mengadakan perubahan sedikit mungkin terhadap model law atau model contract. Teknik model law seringkali merupakan langkah pertama dalam melakukan harmonisasi apabila sama sekali belum ada pengalaman dalam harmonisasi hukum yang sama berlaku bagi ketentuan-ketentuan contoh (model privission) atau model contracts.

\section{Biodata}

* Prof. Dr. Mochtar Kusumaatmadja, SH., adalah mantan Menteri Luar Negri Republik Indonesia. Saat ini aktif mengajar diberbagai Perguruan Tinggi Swasta termasuk UII dan Guru Besar Fakultas Hukum UNPAD Bandung. 